\title{
ENTREPRENEURIAL MOTIVATIONS TO START NEW BUSINESSES: A PANEL DATA ANALYSIS
}

\author{
Ane-Mari ANDRONICEANU ${ }^{a}$, Jani KINNUNEN ${ }^{b}$, Irina GEORGESCU ${ }^{c^{*}}$ \\ ${ }^{a, c}$ Bucharest University of Economic Studies, Romania \\ ${ }^{b}$ Åbo Akademi University, Finland
}

\begin{abstract}
This paper explores the effects of attitudes on total early-stage entrepreneurial activity (TEA). The data is obtained from the Global Entrepreneurship Monitor's Adult Population Surveys (APS) on the characteristics and motivations of individuals to start new businesses. The dataset consists, e.g., of individuals' entrepreneurial intentions, their perceived capabilities, opportunities, and risks as well as the share of female-male entrepreneurs. The time-series for 16 European and Latin American countries together with Taiwan and Iran cover the research period 2011-2019. All countries with long enough time-series data are included. The research methodology tests Random and Fixed Effects Models. The latter model becomes selected leading to a model explaining 95\% $\left(R^{2}\right)$ of the variation in TEA. The results of the rather heterogeneous sample of countries show that when individuals recognize their own capabilities to start and run businesses, they also have entrepreneurial intentions, which both have great significant positive effects on the early-stage entrepreneurial activity. Interestingly, fear of failure, which may prevent individuals to start a business, had also positive effects on TEA. This suggests that fear of failure goes hand-in-hand with the willingness to start new businesses. Further, testing the predictive power of the obtained Fixed Effects Model demonstrated it highly accurate. For future research, countries may be clustered by their attitudes and entrepreneurial conditions, which were not considered in this study, when timeseries analysis may reveal different set of indicators driving entrepreneurship, e.g., in Europe and Latin America.
\end{abstract}

KEYWORDS: entrepreneurship, fixed effects model, forecast error, panel data.

DOI: 10.24818/IMC/2021/03.04

\section{INTRODUCTION AND LITERATURE}

The term entrepreneurship began to be used by economists in the eighteenth and nineteenth centuries, overlapping with the period of the Industrial Revolution. Entrepreneurship is perceived as the result of native personal qualities that few people possess. In reality, entrepreneurship consists in the successful initiation of businesses as a result of a set of environmental, personal and social factors (e.g., Bencsik et al., 2018) that can be developed through education and training (Krisnaresanti et al., 2020). Entrepreneurship is the process by which individuals or groups attract and use a range of resources in order to exploit and use the business opportunities identified in the environment. Entrepreneurship is a person's ability to turn ideas into actions (Fila et al., 2020), Global Entrepreneurship Monitor (GEM) defines entrepreneurship as any new business or new venture. The starting of the new business and the next step of owning and managing it is called earlystage entrepreneurial activity, shortly TEA. This activity involves innovation, creativity, risk-taking, the ability to plan and manage projects in order to achieve the proposed objectives.

\footnotetext{
*Corresponding author. E-mail address: irina.georgescu@csie.ase.ro
} 
Therefore, an entrepreneur is an economic agent with an active behavior, who assumes financial risks to develop new projects that bring him profit (Ginevičius et al., 2021; Yousif et al., 2020; Kosach et al., 2020; Adams, 2020). A study published by Harvard Business School in November 2017, identifies the personality traits of entrepreneurs are as follows: (1) openness to new experiences - are independent, focused on originality and creativity, easily take risks; (2) conscientiousness - entrepreneurs are oriented on the final goal of the action and always complete the tasks; (3) extraversion - entrepreneurs are energetic, optimistic, sociable, characterized by a high level of assertiveness and emotional intelligence; (4) agreeableness - entrepreneurs are altruistic, oriented on community development, modest and trustworthy; (5) neuroticism - entrepreneurs are capable of negative emotions and can become sad, anxious, tense under stress.

Entrepreneurship is characterized by a number of traits: inner control in difficult situations, perseverance, planning ability, constructive feedback and analysis in decision making. In general, most business ideas fall into three general categories: (1) services: tourism, painting, decoration, babysitting, housekeeping are just a few examples; (2) trade: retail, wholesale, e-mail order, telephone sale, door-to-door sales; (3) production: when it comes to small businesses, production refers to areas such as handicrafts, clothing, jewellery, small farms, small furniture.

The European Union promotes entrepreneurship and emphasizes the importance of developing a culture based on competitiveness that helps countries' economies (Androniceanu \& Marton, 2021; Androniceanu et al., 2021; Androniceanu, 2020; Bayar et al. 2020; Kinnunen et al., 2019). That is because entrepreneurship is the vehicle through which the economic system is entered (Meyer \& Krüger, 2021). Economic growth and the number of jobs in Europe depend on the ability to support the development of entrepreneurial conditions including economic freedoms and competitiveness of companies (Georgescu et al., 2018, 2020; Georgescu \& Kinnunen, 2019; Kinnunen et al., 2021; Haseeb at al. 2019; Androniceanu A.- M. et al., 2020).

Entrepreneurship creates new businesses, (Godany et al., 2021) opens new markets and encourages the acquisition of new skills. The most important sources of job creation are small and medium enterprises (Kowo et al, 2019; Grondys et al., 2021; Siekelova et al. 2020; Borocki et al. 2019; Mura \& Hajduová, 2021; Muangmee et al., 2021; Sroka \& Meyer, 2021). They positively influence the labour market due to the steep development of new jobs with high innovative potential (Hu et al., 2019; Androniceanu, 2021) and consequently growing demand for skilled employees (Bilan et al., 2020; Stacho et al., 2019). Therefore, the objective of the European Commission is to encourage citizens to become entrepreneurs and to create conditions for them to be able to open and grow their own business (Tamulevičienè \& Androniceanu, 2020; Slávik et al., 2021). 37\% of European citizens would like to have their own business, a smaller percentage than in the United States and China, where $51 \%$ of citizens want to become entrepreneurs. The challenges for the Europeans' willingness to start businesses include:

(i) the education system should provide the necessary foundations for an entrepreneurial career;

(ii) difficult access to finance and markets;

(iii) difficulty in transferring business; (iv) fear of "punitive" sanctions in case of failure;

(iv) cumbersome administrative procedures.

There are various EU funds available for start-ups. Some examples are the COSME, InnovFin, Creative Europe, EaSI (Program for Employment and Social Innovation, ESI (European Structural and Investment Funds), European Investment Bank and European Investment Fund programs. The European Commission's Startup Europe Club initiative is very useful for those who want to find out what EU funds are right for their needs and want to look for funding opportunities. Furthermore, the Startup Europe Partnership platform helps entrepreneurs who want to expand and develop their business.

According to the report published by the World Economic Forum, "Europe's Hidden Entrepreneurs: Entrepreneurial Employee Activity and Competitiveness in Europe", Romania is in the Top 10 of the countries in Europe with the most intense entrepreneurial activity. The report analyzed a form of 
entrepreneurship that goes beyond the usual start-up - "intrapreneurship" - a term that refers to the involvement of employees in the implementation of new ideas in the company in which they work, an activity called EEA. According to the report, entrepreneurs in Europe often choose to start new projects while working for their employers. The report compares entrepreneurial activity within organizations with start-ups called TEA ("total early-stage entrepreneurial activity") in the graphs below. In Europe, a higher proportion of entrepreneurial activity is manifested through the EEA than anywhere else in the world: $40 \%$ of entrepreneurs are EEA entrepreneurs, compared to $29 \%$ in the US.

Entrepreneurship is a process that includes several stages:

(1) Identifying the opportunity. The opportunity can be triggered by the possibility of obtaining a good or service faster, more efficiently or at a higher quality. At the same time, it can be influenced by various factors, such as: (a) changes in the structure of an industrial sector or a market; (b) changes in demographics or buying and consuming behaviors; (c) lifestyle changes at the target group level; (d) the emergence of new technologies.

The business idea must respond to a need in the market, to differentiate itself from the competition, to cover the marketing mix, which refers to a product or service, price, promotion, distribution, to be an idea that can be applied over time. useful, to be sustainable (Gray-Hawkins \& Lăzăroiu, 2020).

(2) Identifying the necessary resources. Resources differ depending on the profile and size of the business, but most often include primarily the entrepreneur or business developer, his time, labor, logistics of distribution methods, raw materials, financial resources, locations, licenses, machinery and equipment and share capital (Nicolescu et al, 2020; Haque at al., 2019).

(3) Obtaining and using the necessary resources. The entrepreneur must focus on ensuring the long-term financing of the current activity. As a general rule, entrepreneurs use mainly four categories of financiers of their new business ideas: family, friends or business angels, banks and non-reimbursable funds, the most current and profitable source.

(4) Business implementation and management. Leadership is an important component of entrepreneurship and the more efficiently a business uses the resources at its disposal, the better it obtains results that differentiate it in the market. Effective business management involves leadership vision by using the results obtained to grow the business and attack new profitable markets (Çera et al. 2020; Mircica, 2020).

Regardless of the specifics of the company, the field in which it operates or the profit figure, it is influenced by certain factors that represent real challenges that leave their mark, positively or negatively. The factors that influence entrepreneurship are of several types:

(i) Legislative-normative factors. These factors are controlled by the Romanian state, its institutions and the regulations of the European Union. Directly targets laws, acts, government ordinances, special provisions or other draft laws that influence the entrepreneurial environment.

(ii) Social factors. These factors are represented by the relationship with suppliers, customers (possible and current), state organizations, potential collaborators, and business partners. Regarding the internal social factors with a determining role in the activity of a company, the employees have the greatest impact (Ciobanu et al., 2019; Istianingsih et al., 2020; Davies et al., 2020). Belas et al. (2020) based on 822 SMEs from Czech and Slovak business environment said, that the owner (manager) of the company should regularly evaluate the performance of its subordinates and motivate them to innovate in work processes. Čepel (2019) on base the perception and attitudes of 632 Czech and Slovak entrepreneurs said, that the family environment motivates them to do business and helps them with their entrepreneurial activities.

(iii) Financial factors. Loans, European funds, and government loans can be part of the financial factors. 
(iv) Technological factors. These factors refer to the technological evolution and to the power of adapting the business to the new technologies. Depending on the specifics of the company, these factors can influence a company's productivity.

(v) Political factors. These primary factors underlie the development of the entrepreneurial environment, because the political regime decisively influences the appearance or development of the entrepreneurial environment in a certain country or geographical area.

(vi) Macroeconomic factors. These global factors include events in the world's strong economies, the policy of states that have a monopoly on a particular market, conflicts, wars, agreements on the movement of goods or the latest discoveries in the field.

When the TEA and EEA entrepreneurship are combined, a surprising list of the most entrepreneurial countries in Europe is discovered. The Baltic countries are very entrepreneurial, and Romania is also in the top 10 of the most entrepreneurial countries in Europe, a top in which Germany and France, two of the largest economies in Europe, do not qualify.

We will apply the fixed effect model for panel data for 16 world countries for the period 2011-2019, studying the determinants of TEA using Global Entrepreneurship Monitor database for the estimation of entrepreneurial activity conducted by their survey methodology.

Several papers dealt with the panel data approach to entrepreneurship and its determinants. Sadraoui and Ammari (2017) study the impact of entrepreneurship and business freedom on economic growth for a panel data of developing countries for 2004-2017. A conclusion of the study is that the entrepreneurial activities for working males have no impact on economic growth, while business freedom and entrepreneurial activities for working females and business freedom have a positive significant influence.

Rusu and Dornean (2019) apply panel data regression models for EU countries for 2011-2017 and find that competitiveness is positively correlated with innovation rate and FDI, while negatively correlated with taxes, costs and job creation. Konstantinos and Karkalakis (2015) build a panel VAR model for 30 OECD countries for 1970-2011 considering entrepreneurship, unemployment and economic growth. They estimate each of the three VAR equations with GMM estimators.

Katekhaye et al. (2019) study the Indian agricultural entrepreneurial activities and find that the motivation of a rural entrepreneur to start a business depends on his education and income. Meyer and Meyer (2020) analyze the causality between entrepreneurial intent, TEA, established business ownership and GDP per capita for a five-country panel dataset by FMOLS and DOLS.

Kinnunen and Georgescu (2020) apply multiple correspondence analysis in order to categorize 49 world countries according to 27 variables. Secondly, neural networks are used to find the model performance for each TEA category. Paper by Kinnunen et al. (2021) applies fuzzy time series and the vector error correction model VEC to investigate the micro and meso level factors having the greatest impact on entrepreneurial activity during 2011-2019 and report 1-3-year lagged effects of conditions and motivations on TEA.

With regard to the literature, our work has a significant contribution because it identifies and analyzes the changes that have taken place in entrepreneurship over a long period of time. There are studies in the literature that punctually analyze certain changes. Our paper contains the results of a dynamic analysis over a period of 10 years. These scientific results are distinguished both by the method of data processing and by the consistency and relevance of the results obtained.

Data variables are defined and research methodology with the applied models are described in section 2. The Fixed and Ramdom Effects models are put under tests and the model outcome with the prediction ability are presented in section 3. Section 4 concludes the paper with discussion of results together with the limitations of this study and the suggestions for some possible future research directions. 


\section{DATA AND RESEARCH METHODOLOGY}

The 16 countries included in the study are: Brazil, Chile, Colombia, Croatia, Germany, Greece, Iran, Ireland, Poland, Slovakia, Slovenia, Spain, Sweden, Switzerland, Taiwan and UK. The data has been collected from Global Entrepreneurship Monitor (GEM), whose survey experts conduct Adult Population Surveys (APS) in over 60 countries worldwide.

All countries and variables from the GEM database, which are available for years 2011-2019, are selected based on the requirements for the proper time-series analysis. In Table 1, the indicators with their definitions, average values and standard deviations are presented.

The dependent variable is Total early-stage entrepreneurial activity (TEA), i.e., V1 in Table 1. Indicators V2-V9 are the independent variables.

The data units are percentages (\%) of respondents of 18-64-year-old population, except for Female/male TEA, the unit is a percentage of all 18-64-year-old females as entrepreneurs divided the corresponding percentage of males as entrepreneurs (i.e., \%/\%).

Table 1. Variable definitions and descriptive statistics

\begin{tabular}{|c|c|c|c|}
\hline Variable & Definition & Average & Std.dev. \\
\hline V1 & $\begin{array}{l}\text { Total early-stage entrepreneurial activity (TEA), \% of the } \\
\text { population (18-64-year-old) who are either a nascent } \\
\text { entrepreneur or owner-manager of a new business }\end{array}$ & 10.719 & 6.142 \\
\hline $\mathrm{V} 2$ & $\begin{array}{l}\text { Perceived opportunities, \% of the population who see good } \\
\text { opportunities to start a firm }\end{array}$ & 39.607 & 17.215 \\
\hline V3 & $\begin{array}{l}\text { Perceived capabilities, \% of the population who believe they } \\
\text { have the required skills and knowledge to start a business }\end{array}$ & 48.713 & 9.783 \\
\hline V4 & $\begin{array}{l}\text { Fear of failure rate, \% of the population who indicate that } \\
\text { fear of failure would prevent them from setting up a business }\end{array}$ & 36.905 & 7.225 \\
\hline V5 & $\begin{array}{l}\text { Entrepreneurial intentions, \% of the population who are } \\
\text { latent entrepreneurs and who intend to start a business } \\
\text { within } 3 \text { years }\end{array}$ & 18.941 & 14.073 \\
\hline V6 & $\begin{array}{l}\text { Established business ownership, \% of the population who } \\
\text { are currently an owner-manager of an established (running } \\
\text { more than } 42 \text { months) business }\end{array}$ & 8.331 & 3.534 \\
\hline V7 & $\begin{array}{l}\text { Female/male TEA, \% of the population who are either a } \\
\text { nascent entrepreneur or owner-manager of a 'new business', } \\
\text { divided by the equivalent \% for their male counterparts }\end{array}$ & 62.229 & 17.177 \\
\hline V8 & $\begin{array}{l}\text { High job creation expectation, \% of the population nvolved } \\
\text { in TEA who expect to create } 6 \text { or more jobs in } 5 \text { years }\end{array}$ & 24.774 & 11.685 \\
\hline V9 & $\begin{array}{l}\text { Business services sector, \% of the population involved in } \\
\text { TEA in the sector of business services (incl. information and } \\
\text { communication, financial intermediation and real estate, } \\
\text { professional services, or administrative services) }\end{array}$ & 23.811 & 8.865 \\
\hline
\end{tabular}

Source: own research with definitions from https://www.gemconsortium.org/wiki/1154

From Table 1, we note that on average, $10.7 \%$ of 18-64-old-population respondents are counted as early-stage entrepreneurs (V1) and the greatest share of respondents, $48.7 \%$. perceive themselves capable (V3) as entrepreneurs, while $39.6 \%$ have identified good opportunities to start a business in the area, where they live, with $24.8 \%$ expecting to be able to create 6 or more jobs in next 5 years (V8), while $36.9 \%$ report fearing the failure in their possible entrepreneurial activity. The other 
shares are smaller (except the ration of Female-male entrepreneur percentages (V7), 62.2, implying that greater share of females start new businesses than of males.

Figure 1 shows the box plots of all indicators for each country. Table 1 showed that the greatest variation during 2011-2019 is seen in the indicators of Perceived opportunities (V2), Female/male TEA (V7) and Entrepreneurial conditions, while the smallest deviations were seen in Established business ownership (V6) and the dependent variable, TEA (V1).

The box plots show the data for individual countries: Perceived opportunities (V2) vary the most in Poland, Slovenia and Ireland and Female/male TEA (V7) deviates the most in Switzerland, Poland, Greece, and Colombia. The highest level of early-stage entrepreneurial activity (TEA) takes place in Latin American countries of Chile, Colombia, and Brazil. Also, Iran shows higher TEA shares than Europe, which is led by Slovakia, Ireland, and Croatia.

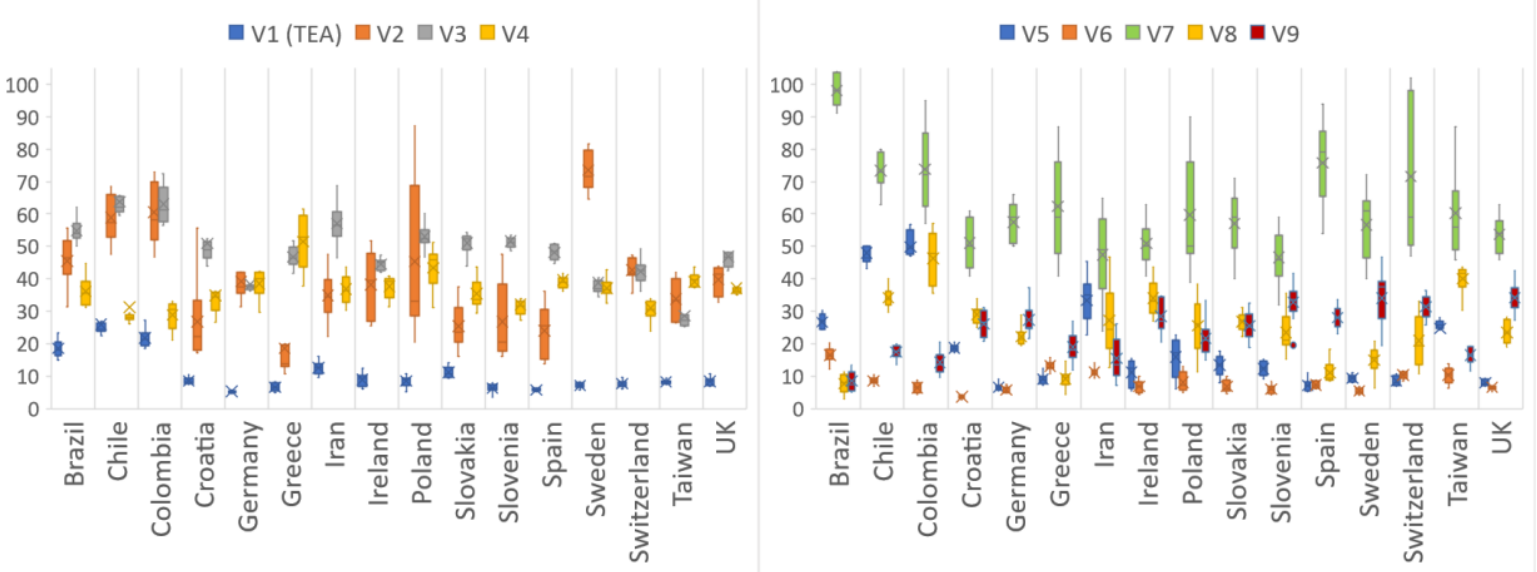

Figure 1. Box plots of indicators in 2010-2019

Source: own research

We use pooled OLS and fixed/random effects estimators. The pooled OLS estimator assumes that the cross-sectional units are identical, therefore heterogeneity is ignored. Fixed effects estimator assumes the unobserved heterogeneity across the cross-sectional units. The Hausman test (Hausman, 1978) compares the random effects and the fixed effects estimator. The null hypothesis of the Hausman test for endogeneity is that the random effects estimator is preferred, while the alternative hypothesis is that the fixed effects estimator is preferred. If the p-value of the statistical test exceeds the critical value, then the null hypothesis is rejected and the fixed effects model is accepted. Equivalently, the null hypothesis asserts that the random effects $\delta_{i}$ are independent of regressors.

The panel data model to be estimated has the form (see Equation 1):

$$
\begin{aligned}
& V 1_{i, t}=a_{1}+a_{2} V 2_{i, t}+a_{3} V 3_{i, t}+a_{4} V 4_{i, t}+a_{5} V 5_{i, t}+a_{6} V 6_{i, t}+ \\
& a_{7} V 7_{i, t}+a_{8} V 8_{i, t}+a_{9} V 9_{i, t}+\delta_{i}+\varepsilon_{i, t}
\end{aligned}
$$

where $a_{i}, i=1, \ldots, 9$ are the coefficients to be estimated, $\delta_{i}$ are (fixed or random) specific effects for the cross-sectional units, and $\varepsilon_{i, t}$ is the residual term, $i=1, \ldots, T, t=1, \ldots, T, \mathrm{i}=$ country index, $\mathrm{t}=$ time index. $\mathrm{T}$ is the number of periods (9 years: 2011-2019) and $\mathrm{N}=$ the number of countries (16). $\delta_{i}$ are country-specific intercepts that express heterogeneity across countries (Hank et al., 2020). 


\section{RESULTS}

By means of Redundant Fixed Effects Tests we will compare the pooled OLS regression (POLS) and a panel model (Baltagi, 2014). The null hypothesis of the Redundant Fixed Effects Tests is that POLS is preferred, while the alternative hypothesis is that fixed effects estimator is preferred. Since both probabilities in Table 2 are less than 0.05, the null hypothesis is rejected, and fixed effects estimator is preferred.

Table 2. Summary of the Redundant Fixed Effects Test

\begin{tabular}{|l|c|r|c|}
\hline \multicolumn{1}{|c|}{ Effects test } & Statistic & \multicolumn{1}{c|}{ d.f. } & Prob. \\
\hline Cross-section F & 17.048386 & -15.120 & 0.0000 \\
\hline Cross-section Chi-square & 164.356969 & 15 & 0.0000 \\
\hline
\end{tabular}

Source: own computations

The next step is to decide between FEM and random effects model (REM) by Hausman test. The null hypothesis of the Hausman test is that REM is preferred, while the alternative hypothesis is that FEM is preferred. The null hypothesis of the Hausman test asserts in other words that the errors are not correlated with the regressors (Torres-Reyna, 2010). The p-value of the Hausman test is $0.0063<0.05$ (Table 3), therefore, one rejects the null hypothesis and decides that FEM is the appropriate model. Find definitions of variables V1-V9 definitions in Table 1.

Table 3. Summary of the Hausman test

\begin{tabular}{|c|r|r|r|r|}
\hline Test Summary & & Chi-Sq. statistic & Chi-Sq. d.f. & Prob. \\
\hline Cross-section random & \multicolumn{5}{|c|}{21.348183} & 8 & $\mathbf{0 . 0 0 6 3}$ \\
\hline \multicolumn{7}{|c|}{ Cross-section random effects test comparisons } \\
\hline Variable & \multicolumn{1}{|c|}{ Fixed } & Random & \multicolumn{1}{c|}{ Var(Diff.) } & Prob. \\
\hline V2 & -0.017770 & -0.005714 & 0.000025 & $\mathbf{0 . 0 1 6 0}$ \\
\hline V3 & 0.155241 & 0.169802 & 0.000175 & 0.2707 \\
\hline V4 & 0.074412 & 0.027079 & 2.748010 & $\mathbf{0 . 0 0 0 8}$ \\
\hline V5 & 0.120381 & 0.039828 & 3.022534 & $\mathbf{0 . 0 0 1 9}$ \\
\hline V6 & 0.140194 & 0.089251 & 1.570779 & 0.5854 \\
\hline V7 & -0.344299 & 1.290894 & -0.266714 & 0.0955 \\
\hline V8 & -0.024031 & 0.02821 & -0.851839 & 0.7779 \\
\hline V9 & -0.097408 & 0.029855 & -3.262667 & 0.3292 \\
\hline \multicolumn{5}{|l}{ Source: own computations } \\
\end{tabular}

According to Table 4, FEM is statistically significant $\left(\mathrm{R}^{2}=0.94\right)$, and the model fits perfectly to the dataset. Adjusted $\mathrm{R}^{2}$ is 0.93 , which means that about $93 \%$ of TEA variation is explained by the independent variables. Durbin Watson statistics are 1.78, close to 2, indicative of uncorrelated errors.

The found fixed effects can be justified by the country-specific aspects, which were seen pretty stable over time. One can see that V3, V4, V5 and V9 are statistically significant at 5\% significance level.

A $1 \%$ increase in Perceived capabilities leads to an increase of $0.16 \%$ in TEA. A $1 \%$ increase in fear of failure rate leads to an increase of $0.07 \%$ in TEA. A $1 \%$ increase in Entrepreneurial intentions leads to an increase of $0.12 \%$ in TEA. A $1 \%$ increase in the services of the business sector leads to a $0.09 \%$ decrease in TEA. These correlations are in accordance with economic theory. The other regressors including Perceived opportunities, Established business ownership, Female/male TEA and High job creation expectation are not statistically significant under the Fixed Effects Model. 
Table 4. Summary of FEM determinants of TEA

\begin{tabular}{|c|r|r|r|r|}
\hline Variable & Coefficient & Std. error & t-statistic & \multicolumn{1}{c|}{ Prob. } \\
\hline C & 0.795259 & 2.057964 & 0.386430 & 0.6999 \\
\hline V2 & -0.017770 & 0.014810 & -1.199907 & 0.2325 \\
\hline V3 & $\mathbf{0 . 1 5 5 2 4 1}$ & $\mathbf{0 . 0 3 3 3 1 0}$ & $\mathbf{4 . 6 6 0 5 0 2}$ & $\mathbf{0 . 0 0 0 0}$ \\
\hline V4 & $\mathbf{0 . 0 7 4 4 1 2}$ & $\mathbf{0 . 0 2 7 0 7 9}$ & $\mathbf{2 . 7 4 8 0 1 0}$ & $\mathbf{0 . 0 0 6 9}$ \\
\hline V5 & $\mathbf{0 . 1 2 0 3 8 1}$ & $\mathbf{0 . 0 3 9 8 2 8}$ & $\mathbf{3 . 0 2 2 5 3 4}$ & $\mathbf{0 . 0 0 3 1}$ \\
\hline V6 & 0.140194 & 0.089251 & 1.570779 & 0.1189 \\
\hline V7 & -0.344299 & 1.290894 & -0.266714 & 0.7901 \\
\hline V8 & -0.024031 & 0.028210 & -0.851839 & 0.3960 \\
\hline V9 & $\mathbf{- 0 . 0 9 7 4 0 8}$ & $\mathbf{0 . 0 2 9 8 5 5}$ & $\mathbf{- 3 . 2 6 2 6 6 7}$ & $\mathbf{0 . 0 0 1 4}$ \\
\hline \multicolumn{7}{|c|}{ Cross-section fixed (dummy variables) } & \\
\hline Root MSE & 1.424810 & R-squared & & 0.946182 \\
\hline Mean dependent var & 10.71896 & Adjusted R-squared & & 0.935867 \\
\hline S.D. dependent var & 6.163205 & S.E. of regression & & 1.560801 \\
\hline Akaike info criterion & 3.879287 & Sum squared resid & & 292.3318 \\
\hline Schwarz criterion & 4.374256 & Log likelihood & & -255.3086 \\
\hline Hannan-Quinn criter. & 4.080414 & F-statistic & & 91.72788 \\
\hline Durbin-Watson stat & 1.781169 & Prob(F-statistic) & & 0.000000 \\
\hline
\end{tabular}

Source: own computations

Next, we forecast the TEA for 2020 and 2021 (cf. Figure 2).

Root Mean Squared Error (RMSE) and Mean Absolute Error (MAE) are the most commonly used measurements although they depend on the measurement scale of the data used, and can only be used to compare forecast models for the same data. The RMSE is the standard deviation of the forecasted errors, i.e. the difference between the actual and forecasted values. The lower its value, the better the model prediction. MAE is also expected to be as low as possible for the best prediction model.

The Inequality coefficient measures the accuracy with which the forecast was made and takes values from 0 to 1 , value 0 indicating a perfect prediction. In this case Theil Inequality coefficient equals 0.057860 , pointing out to a good forecast accuracy.

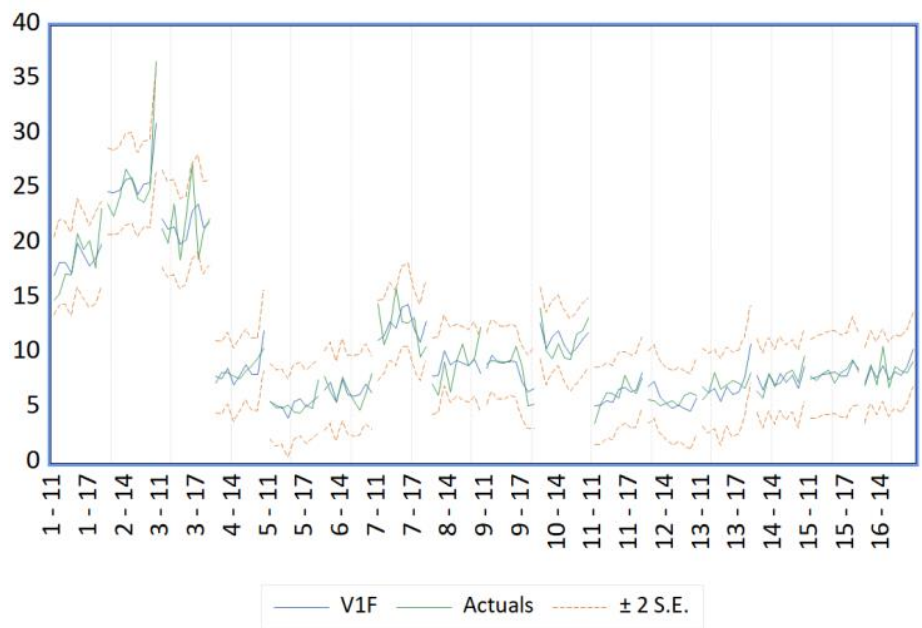

Figure 2. TEA forecast for 2020-2021

Source: own computation

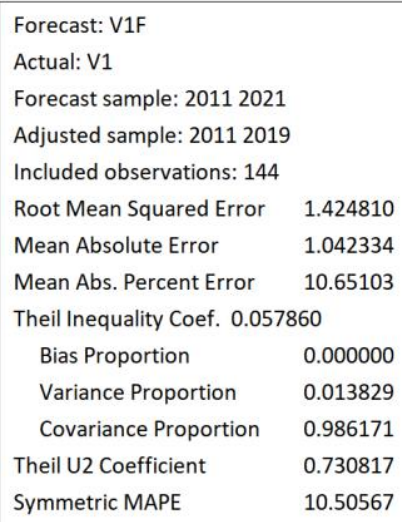


Bias Proportion indicates how far away the average prediction is from the average of the real data. Variance Proportion shows how far from the variance of the forecast series from that of the actual series. Covariance Proportion non-systematic prediction errors. The sum of the three proportions is 1. For a good quality of forecasting, the first two proportions should be as small as possible, and the covariance proportion should be larger. In our case, the Bias Proportion is 0, the Variance Proportion is 0.013829. Symmetric Mean Absolute Percentage Error (sMAPE) measures the accuracy of the forecast on the basis of percentage errors and has a good value, $10.50 \%$.

Hence, we conclude that the TEA forecast for 2020-2121 for the panel of 16 countries is very accurate.

\section{CONCLUSIONS}

This paper explored the effects of attitudes on total early-stage entrepreneurial activity (TEA). The data was obtained from the Global Entrepreneurship Monitor's Adult Population Surveys (APS) on the characteristics and motivations of individuals to start new businesses.

The dataset consisted, e.g., of individuals' entrepreneurial intentions, their perceived capabilities, opportunities, and risks as well as the share of female-male entrepreneurs. The time-series for 16 European and Latin American countries together with Taiwan and Iran covered the period 20112019. All countries with long enough time-series data were included. The research methodology tested Random and Fixed Effects Models. The REM hypothesis was rejected. The acceptance of FEM is more plausible since the cross-sections are countries and the omitted effects are fixed in nature, not random. The latter model became selected leading to a model explaining $94.6 \%$ (R2) of the variation in TEA, as a result of the Hausman test.

The results of the rather heterogeneous sample of countries showed that when individuals recognize their own capabilities to start and run businesses, they also have entrepreneurial intentions, which both have great significant positive effects on the early-stage entrepreneurial activity with regression coefficients of 0.16 and 0.12 , respectively. Interestingly, fear of failure, which may prevent individuals to start a business, had also positive effects on TEA with the coefficient of 0.07 . This suggests that fear of failure goes hand-in-hand with the willingness to start new businesses. The larger the relative size of the business services sector, instead, had negative effect on TEA. Further, testing the predictive power of the obtained Fixed Effects Model demonstrated it highly accurate. Perceived opportunities, established business ownership, female/male TEA, and high job creation expectation were statistically insignificant. A dynamic AR-model of Kinnunen et al. (2021) suggested that perceived opportunities affect negatively in one year, but after two years the effect is positive both for perceived opportunities and established businesses. While Meyer and Meyer (2020) found that TEA together with established business ownership were significant drivers of GDP, while entrepreneurial intention was not significant, our results suggest that the last one is important through its effect on TEA but the effect of established businesses may be direct as our results didn't find it significant contributor through TEA.

Some limitations of this research can be noted. Firstly, while, all countries from GEM database with available data for 9 years of consecutive entrepreneurial motivations and attitudes data were included, the generalization of results may not apply to other countries of the world; secondly, entrepreneurial conditions data were not considered; and, thirdly, our data consisted in mainly European and few Latin American countries, which have rather different attitude on entrepreneurship. Hence, we may get somewhat different results, possibly more statistically significant variables affecting TEA if we restrict the analysis only for European countries, for instance. Fourthly, the time-series analysis was restricted to long-run effects shown by the FEM model, while autoregressive (AR) time-series modelling could revel yearly effects. Fifthly, the error autocorrelation which frequently appears in OLS-based panel models can be corrected by dynamic models. Then, consistent estimators are Arellano and Bond (1991) or Arellano and Bover (1995) 
estimators. For other future research possibilities, countries may be clustered by their motivations, attitudes, and entrepreneurial conditions, which were not considered in this study, when time-series analysis may reveal different set of indicators driving entrepreneurship, e.g., in Europe and Latin America, or simply, only European countries can be taken under analysis. Also, this research will be continued with the application of alternative panel data models, such as GMM estimators and quartile regression analysis.

\section{ACKNOWLEDGMENT}

The paper is part of Ane-Mari Androniceanu's doctoral research program at the Doctoral School of Management at Bucharest University of Economic Studies.

\section{REFERENCES}

Adams, C. (2020). Smart sustainable urban mobility behaviors: public attitudes and adoption intentions concerning self-driving cars. Contemporary Readings in Law and Social Justice, 12(1), 16-22. doi:10.22381/CRLSJ12120202.

Androniceanu, A. (2020). Major structural changes in the EU policies due to the problems and risks caused by COVID-19. Administratie si Management Public, 34, 137-149. doi:10.24818/amp/2020.34-08.

Androniceanu, A. (2021). Transparency in public administration as a challenge for a good democratic governance. Administratie si Management Public, 36, 149-164. DOI: 10.24818/amp/2021.36-09.

Androniceanu, A., Kinnunen, J. \& Georgescu, I. (2021). Circular economy as a strategic option to promote sustainable economic growth and effective human development. Journal of International Studies, 14(1), 60-73. doi:10.14254/2071- 8330.2021/14-1/4.

Androniceanu, A. \& Marton, D., M. (2021). The psychosocial impact of the Romanian government measures on the population during the COVID-19 pandemic. Central European Public Administration Review, 19(1), 7-32, doi:10.17573/cepar.2021.1.05.

Androniceanu, A., M., Georgescu, I., Tvaronavičiene, M. \& Androniceanu, A. (2020). Canonical Correlation Analysis and a New Composite Index on Digitalization and Labor Force in the Context of the Industrial Revolution 4.0. Sustainability, 12(17), Article number: 6812, https://doi.org/10.3390/su12176812; https://www.mdpi.com/2071-1050/12/17/6812.

Arellano, M. \& Bond, S. (1991). Some tests of specification for panel data: Monte Carlo evidence and an application to employment equations. Review of Economic Studies, 58(2): 277. doi:10.2307/2297968. JSTOR 2297968.

Arellano, M. \& Bover, O. (1995). Another Look at the Instrumental Variable Estimation of ErrorComponents Models. Journal of Econometrics, 68, 29-51.

Baltagi, B. (2014). Panel data econometrics. $1^{\text {st }}$ edition, Routledge.

Bayar, Y., Remeikiene, R., Androniceanu, A., Gaspareniene, L. \& Jucevicius, R. (2020). The shadow economy, human development and foreign direct investment inflows. Journal of Competitiveness, 12(1), 5-21. doi:10.7441/joc.2020.01.01.

Belas, J., Amoah, J., Petráková, Z., Kliuchnikava, Y. \& Bilan, Y. (2020). Selected Factors of SMEs Management in the Service Sector. Journal of Tourism and Services, 21(11), 129-146. doi:10.29036/jots.v11i21.215.

Bencsik, A., Kosár, T.S., \& Machová, R. (2018). Corporate Culture in Service Companies that Support Knowledge Sharing. Journal of Tourism and Services, 9(16): 7-13. doi:10.29036/jots.v9i16.41 
Bilan, Y., Mishchuk, H., Roshchyk, I. \& Joshi, O. (2020). Hiring and retaining skilled employees in SMEs: problems in human resource practices and links with organizational success. Business: Theory and Practice, 21(2), 780-791. doi:10.3846/btp.2020.12750.

Borocki, J., Radisic, M., Sroka, W., Greblikaite, J. \& Androniceanu, A. (2019). Methodology for strategic posture determination of SMEs - the case from a developing country, Inžinerine Ekonomika-Engineering Economics, 30(3), 265-277. doi:105755/j01.ee.30.3.21966.

Čepel, M. (2019). Social and Cultural Factors and Their Impact on the Quality of Business Environment in the SME Segment. International Journal of Entrepreneurial Knowledge, 7(1), 65-73. doi:10.37335/ijek.v7i1.88.

Çera, G., Phan, Q., P., T., Androniceanu, A. \& Çera, E. (2020). Financial Capability and Technology Implications for Online Shopping. E\&M Economics and Management, 23(2), 156172. doi:10.15240/tul/001/2020-2-011.

Ciobanu, A, Androniceanu, A \& Lazaroiu, G. (2019). An integrated psycho-sociological perspective on public employees' motivation and performance. Frontiers in Psychology, 10; Article number: 36. doi:10.3389/fpsyg.2019.00036.

Davies, S., Kovacova, M. \& Valaskova, K. (2020). Urban big data and internet of things sensing infrastructures in smart and environmentally sustainable cities. Geopolitics, History, and International Relations, 12(2), 72-78. doi:10.22381/GHIR122202010.

Fila, M., Levicky, M., Mura, L., Maros, M. \& Korenkova, M. (2020). Innovations for Business Management: Motivation and Barriers. Marketing and Management of Innovations, 4, 266-278. doi:10.21272/mmi.2020.4-22.

Georgescu, I. \& Kinnunen, J. (2019). Well-being and Economic Freedoms in OECD. Proceedings of the 12th LUMEN International Scientific Conference Rethinking Social Action (LUMEN RSACVP2019), Iasi, Romania, 107-125. doi: 10.18662/lumproc.158.

Georgescu, I., Androniceanu, A. \& Kinnunen, J. (2018). A Computational Analysis of Economic Freedom Indicators and GDP in EU States. Proceedings of the 17th International Conference on Informatics in Economy (IE 2018), Iasi, Romania, pp. 461-468.

Georgescu, I., Kinnunen, J., Androniceanu, A. \& Androniceanu, A., M. (2020). A Computational Approach to Economic Inequality, Happiness and Human Development. Informatica Economica, 24(4), 16-27. doi:10.24818/issn14531305/24.4.2020.02.

Ginevičius, R., Szczepańska-Woszczyna, K., Szarucki, M., Stasiukynas, A. (2021). Assessing alternatives to the development of administrative-economic units applying the FARE-M Method. Administratie si Management Public, 36, 6-24. DOI: 10.24818/amp/2021.36-01.

Godany, Z., Machova, R., Mura, L. \& Zsigmond, T. (2021). Entrepreneurship Motivation in the 21 st Century in Terms of Pull and Push Factors. TEM JOURNAL-Technology Education Management Informatics, 10(1), 334-342. doi:10.18421/TEM101-42.

Gray-Hawkins, M. \& Lăzăroiu, G. (2020). Industrial artificial intelligence, sustainable product lifecycle management, and internet of things sensing networks in cyber-physical smart manufacturing systems. Journal of Self-Governance and Management Economics, 8(4), 19-28. doi:10.22381/JSME8420202.

Grondys, K., Slusarczyk, O., Hussain, H., I. \& Androniceanu, A. (2021). Risk assessment of the SME sector operations during the COVID-19 pandemic. Int. J. Environ. Res. Public Health, 18, 4183. doi: $10.3390 /$ ijerph18084183.

Hanck, C., Arnold, M., Gerber, A. \& Schmelzer, M. (2020). Introduction to Econometrics with R. Open Access, Available at https://www.econometrics-with-r.org/index.html.

Haque, U., A., Kot, S. \& Imran, M. (2019). The moderating role of environmental disaster in relation to microfinance's non-financial services and women's micro-enterprise sustainability. Journal of Security and Sustainability Issues, 8(3), 355-373. doi:10.9770/jssi.2019.8.3(6). 
Haseeb, M., Hussai, H., I., Kot, S., Androniceanu, A. \& Jermsittiparsert, K. (2019). Role of Social and Technological Challenges in Achieving a Sustainable Competitive Advantage and Sustainable Business Performance. Sustainability, 11(14), Article Number: 3811. doi:10.3390/su11143811.

Hausman, J. (1978). Specification test in econometrics. Econometrica, 46, pp. 1251-1272, doi:10.2307/1913827.

Hu, X., Ocloo, C., E., Akaba, S. \& Worwui-Brown, D. (2019). Effects of business to business ecommerce adoption on competitive advantage of small and medium-sized manufacturing enterprises. Economics and Sociology, 12(1), 80- 99. doi:10.14254/2071-789X.2019/12-1/4.

Istianingsih, N., Masnun, A. \& Pratiwi, W. (2020). Managerial performance models through decision making and emotional intelligence in public sector. Administratie si Management Public, 35, 153-166. DOI: 10.24818/amp/2020.35-10.

Katekhaye, D., Meyer, N. \& Magda, R. (2019). Entrepreneurial core motivation as a success factor for rural entrepreneurship in Western India. Polish Journal of Management Studies, 19(2), 218230. doi:10.17512/pjms.2019.19.2.18.

Kinnunen, J. \& Georgescu, I. (2020). Entrepreneurial activity - a matter of microeconomic conditions or macroeconomic freedoms? The 5th Business and Entrepreneurial Economics Conference (BEE-2020), May 2020, Rijeka, Croatia, pp. 88-97.

Kinnunen, J., Androniceanu, A. \& Georgescu, I. (2019). The Role of Economic and Political Features in Classification of Countries-in-Transition by Human Development Index. Informatică Economică, 23(4), 26-40.

Kinnunen, J., Georgescu, I. \& Hosseini, Z. (2021). Drivers of entrepreneurial activity at micro and meso levels: a fuzzy time-series analysis. INFUS 2021: International Conference on Intelligent and Fuzzy Systems, Springer, forthcoming.

Konstantinos, D. \& Karkalakos, S. (2015). Entrepreneurship, growth and unemployment: A panel VAR approach. MPRA Paper No 74660, available at: https://mpra.ub.unimuenchen.de/74660/1/MPRA_paper_74660.pdf.

Kosach, I., Duka, A., Starchenko, G., Myhaylovska, O \& Zhavoronok, A. (2020). Socioeconomic viability of public management in the context of European integration processes. Administratie si Management Public, 35, 139-152. DOI: 10.24818/amp/2020.35-09.

Kowo, S., A., Adenuga, O., A., O. \& Sabitu, O., O. (2019). The role of SMEs development on poverty alleviation in Nigeria. Insights into Regional Development, 1(3), 214-226. doi:10.9770/ird.2019.1.3(3).

Meyer, N. \& Krüger, N. (2021). South African female entrepreneurs' motivational factors: Differences between young and established businesses owners. Forum Scientiae Oeconomia, 9(1), 75-90. doi:10.23762/FSO_VOL9_NO1_5.

Meyer, D., F. \& Meyer, N. (2020). The relationships between entrepreneurial factors and economic growth and development: The case of selected European countries. Polish Journal of Management Studies, 21(2), 268-284. doi:10.17512/pjms.2020.21.2.19.

Mircica, N. (2020). Restoring public trust in digital platform operations: machine learning algorithmic structuring of social media content. Review of Contemporary Philosophy, 19, 8591. doi:10.22381/RCP1920209.

Muangmee, C., Dacko-Pikiewicz, Z., Meekaewkunchorn, N., Kassakorn, N. \& Khalid, B. (2021). Green entrepreneurial orientation and green innovation in small and medium-sized enterprises (SMEs). Social Sciences, 10(4), art. no. 136. doi:10.3390/socsci10040136.

Mura, L. \& Hajduová, Z. (2021). Small and medium enterprises in regions - empirical and quantitative approach. Insights into Regional Development, 3(2), 252-266. doi:10.9770/IRD.2021.3.2(6). 
Nicolescu, L., Tudorache, F., G. \& Androniceanu, A. (2020). Performance risk analysis on mutual funds versus stock exchanges in young financial markets Journal of International Studies, 13(1), 279-294. doi:10.14254/2071-8330.2020/13-1/18.

Rusu, D., V. \& Dornean, A. (2019). The quality of entrepreneurial activity and economic competitiveness in European Union countries: A panel data approach. Administrative Sciences, 9, 35, doi:10.3390/admsci9020035.

Sadraoui, T. \& Ammari, A. (2017). A dynamic panel data analysis for relationship between technological innovation, entrepreneurship and economic growth. Journal of Finance \& Corporate Governance, $1(1), \quad$ p. 31-43, available at: https://www.asjp.cerist.dz/en/article/64963.

Siekelova, A., Androniceanu, A., Durana, P. \& Frajtova Michalikova, K. (2020). Earnings Management (EM), Initiatives and Company Size: An Empirical Study. Acta Polytechnica Hungarica, 17(9), 41-56.

Slávik, Š., Bednár, R., Mišúnová Hudáková, I. \& Zagoršek, B. (2021). Business models of start-ups and their impact on the sustainability of Nascent business. Entrepreneurship and Sustainability Issues, 8(4), 29-52. doi:10.9770/jesi.2021.8.4(2).

Sroka, W. \& Meyer, N. (2021). A theoretical analysis of social entrepreneurship: The case of Poland and South Africa. Journal of Eastern European and Central Asian Research, 8(1), 133148. doi:10.15549/jeecar.v8i1.596.

Stacho, Z., Stachová, K. \& Raišienè, A., G. (2019). Changes in approach to employee development in organizations on a regional scale. Journal of International Studies, 12(2), 299-308. doi:10.14254/2071-8330.2019/12-2/19.

Tamulevičienè, D. \& Androniceanu, A. (2020), Selection of the indicators to measure an enterprise's value and its changes in the controlling system for medium-sized enterprises. Entrepreneurship and Sustainability Issues, 7(3), 1440-1458. doi:10.9770/jesi.2020.7.3(1).

Torres-Reyna, O. (2010). Getting started in fixed/random effects models using R. Online tutorial, Princeton University, available at: https://www.princeton.edu/ otorres/Panel101R.pdf, Accessed on 28.06.2021.

Yousif, N., B., A., Grondys, K., Gad, S. \& Elsayed, W. (2020). Knowledge management in nongovernmental organizations (NGOs). Administratie si Management Public, 35, 90-108. DOI: 10.24818/amp/2020.35-06. 